\section{Short Form 36}

Helga Peter

Marburg, Deutschland

\section{Definition}

Kurzfassung des allgemeinen, störungsübergreifenden Fragebogens zum Gesundheitszustand mit 36 Fragen.

Siehe $\triangleright$,Leistungs-, Schläfrigkeits- und Vigilanzmessung“. 